\title{
PERUBAHAN KOMUNIKASI MASYARAKAT DALAM INOVASI MITIGASI BENCANA DI WILAYAH RAWAN BENCANA GUNUNG MERAPI
}

\author{
Damayanti Wardyaningrum \\ Program Studi Ilmu Komunikasi FISIP Universitas Al Azhar Indonesia \\ Kompleks Masjid Agung Al Azhar Jl. Sisingamangaraja Kebayoran Baru Jakarta \\ Selatan Telp (021) 7244456 email: damayanti@uai.ac.id
}

\begin{abstract}
This study aims to analyze changes in communications in disaster mitigation innovation in communication of society in disaster-prone areas with the events of Mount Merapi eruption in 2010. The method used is descriptive research data collection through observation and interviews with community territory in the hamlet Kalitengahkidul, Glagaharjo village, Sleman, Yogyakarta. The concept used is the diffusion of innovation, information and disaster mitigation. The results showed there were adoption of innovations related to the disaster mitigation community communication. Communication changes occur in the communication tools used, sources of information to determine the evacuation decision making, communication, community groups define the disaster mitigation procedures, sources of information about volcanic activity and the priority that must be performed during emergency response and post-disaster recovery period. Findings of the study after the eruption of 2010 appears attitude residents of disaster-prone region more independent and have the initiative in adopting innovations disaster mitigation, especially in terms of communication among communities in the face of potential disasters that will arise.
\end{abstract}

Keywords: changes in communication, diffusion of innovation, information, disaster mitigation.

\begin{abstract}
Abstrak
Penelitian ini bertujuan untuk menganalisa perubahan komunikasi dalam inovasi mitigasi bencana yang dilakukan masyarakat di wilayah rawan bencana dengan adanya peristiwa erupsi gunung Merapi pada tahun 2010. Metode penelitian yang digunakan adalah deskriptif kualitatif dengan pengumpulan data penelitian melalui observasi wilayah dan wawancara dengan masyarakat di dukuh Kalitengahkidul, Desa Glagaharjo, Sleman, Daerah Istimewa Yogyakarta. Konsep yang digunakan adalah difusi inovasi, informasi dan mitigasi bencana. Hasil penelitian menunjukkan terdapat adopsi terhadap inovasi mitigasi bencana terkait dengan komunikasi masyarakat. Perubahan komunikasi terjadi pada alat komunikasi yang digunakan, sumber informasi untuk menentukan mengambil keputusan evakuasi, komunikasi kelompok masyarakat menentukan prosedur mitigasi bencana, sumber informasi tentang aktivitas gunung dan prioritas yang harus dilakukan pada saat tanggap darurat maupun masa pemulihan pasca bencana. Ditemukan dari hasil penelitian setelah erupsi tahun 2010 muncul sikap warga diwilayah rawan bencana yang lebih mandiri dan memiliki inisiatif dalam mengadopsi inovasi mitigasi bencana khususnya dalam hal komunikasi diantara masyarakat dalam menghadapi potensi bencana yang akan timbul.
\end{abstract}

Kata kunci: perubahan komunikasi, difusi inovasi, informasi, mitigasi bencana. 


\section{Pendahuluan}

Indonesia sebagai wilayah yang memiliki kondisi geografis, geologis, hidrologis, dan demografis yang rawan terhadap terjadinya bencana frekuensi yang cukup tinggi, memerlukan penanganan bencana yang sistematis, terpadu, dan terkoordinasi. Dalam Pasal 1 Undang Undang No.24 tahun 2007 tentang Penanggulangan Bencana, yang dimaksud dengan bencana adalah "peristiwa atau rangkaian peristiwa yang mengancam dan menganggu kehidupan dan penghidupan masyarakat yang disebabkan baik oleh faktor alam, faktor non alam maupun faktor manusia sehingga mengakibatkan timbulnya korban jiwa manusia, kerusakan lingkungan, kerugian harta benda dan dampak psikologis". Dalam undangundang tersebut juga ditetapkan tiga jenis bencana: bencana alam, bencana non alam, dan bencana sosial. Dari ketentuan tersebut maka suatu peristiwa dianggap bencana jika peristiwa itu menimbulkan kerusakan, menimbulkan gangguan pada kehidupan, penghidupan, dan fungsi masyarakat yang mengakibatkan korban dan kerusakan melampaui kemampuan masyarakat setempat untuk mengatasinya dengan sumber daya yang dimiliki. Dapat disimpulkan bahwa kemampuan masyarakat dalam menghadapi bencana adalah hal yang penting. Dari perspektif lain mengenai bencana maka pandangan ekonomi politik melihat suatu fenomena alam seperti badai, gempa banjir, tidak harus menjadi bencana. Peringatan, proteksi, pengetahuan, keahlian, akses, baik terhadap sumber-sumber material dan pengetahuan, jaringan dan sumber-sumber bantuan dapat memitigasi dampak kejadian alam dan meningkatkan kemampuan manusia untuk memulihkan efek yang ditimbulkan. (Blaikie dalam Abdullah: 2008).

Salah satu bencana alam yang penting dikelola adalah letusan gunung berapi.
Terdapat 127 gunung berapi aktif melingkari tanah nusantara. Tantangan tersebut sangat besar mengingat jumlah gunung api aktif (tipe A) di Indonesia mencapai 79 gunung dengan penyebaran sebagai berikut: Sumatera (13), Jawa (21), Bali (2), Lombok (1), Sumbawa (2), Flores (16), Laut Banda (8), Sulawesi(6), Kepulauan Sangihe (5), dan Halmahera (5).(Oman dkk, 2006). Dengan total 30 gunung berapi di Pulau Jawa maka berarti terdapat 120 juta orang hidup dalam ancaman letusan gunung berapi. Kedekatan warga dengan lokasi gunung berapi telah terbukti fatal karena lebih dari 150.000 jiwa tewas akibat letusan gunung berapi diseluruh nusantara dalam kurun waktu 500 tahun terakhir. Angka ini merupakan rekor dunia. (Kompas, 5 April 2015).

Penelitian ini akan memfokuskan pada masyarakat yang menempati di wilayah rawan bencana alam gunung berapi dengan kajian dari ilmu komunikasi. Selain dari data yang telah dikemukakan diatas, alasan penelitian dengan pemilihan tema tersebut akan disampaikan lebih lanjut dalam uraian dibawah ini. Terkait dengan persoalan mitigasi bencana alam di Indonesia, Ketua Pusat Studi Bencana Alam Universitas Gadjah Mada Junun Sartohadi mengemukakan bahwa sampai saat ini meskipun terdapat perbaikan dalam penanganan bencana namun belum terdapat perubahan besar terkait manajemen bencana. Pengelolaan bencana masih berbasis tanggap darurat, bukan mitigasi. Basis tanggap darurat itu pula yang menyebabkan penanganan bencana masih nampak kacau karena unsur perencanaan bukan menjadi unsur yang utama. Dengan melihat kompleksitasnya persoalan masyarakat di wilayah rawan bencana maka mitigasi juga harus dipandang sebagai tindakan terkait dengan pendidikan bencana. Selama ini pendidikan bencana lebih banyak dilakukan masyarakat yang sering kali tidak menggunakan basis 
keilmuan dan teknologi. Pemerintah bisa membuat perencanaan dengan kombinasi arahan dari atas maupun menggali partisipasi masyarakat. Hal Ini diperlukan agar ikatan-ikatan emosional di masyarakat bisa didekati, masyarakat juga bisa mengerti pendekatan birokrasi yang dilakukan pemerintah. Apabila hal ini dilakukan, sehingga tidak terdengar pernyataan saling menyalahkan seperti ketika masyarakat Merapi menolak mengungsi. Dengan perencanaan yang komprehensif terdiri dari perencanaan bersifat regional dan detail. Perencanaan regional mencakup pemetaan potensi bencana di wilayah masing-masing maka pemahaman atas potensi ancaman menjadi strategi mitigasi. Dalam perencanaan strategi mitigasi ini, pendekatan ilmiah dapat dipertemukan dengan usulan dari masyarakat. (Kompas, 20-12-2010).

Mitigasi diartikan sebagai setiap tindakan yang berkelanjutan yang dilakukan untuk mengurangi atau menghilangkan resiko jangka panjang terhadap harta dan jiwa manusia. Sehingga mitigasi dapat dikatakan sebagai sebuah mekanisme agar masyarakat dapat menghindari dampak dari bencana yang potensial terjadi. Tindakannya dapat berfokus pada penghindaran bencana, khususnya menghindari penempatan manusia dan harta benda di daerah berbahaya. Termasuk usaha untuk mengendalikan bahaya melalui berbagai pembangunan fasilitas khusus dan penerapan teknologi tertentu (Wijanarko, 2006:25).

Bagi masyarakat yang berada di wilayah rawan bencana terdapat enam jenis kerentanan yang dihadapi dalam konteks sosial yang diuraikan oleh David dan Alexander dalam Özerdem dkk (2006). Pertama, kerentanan ekonomi yaitu terdapat kondisi yang termarginalkan dalam memperoleh penghasilan selama terjadi bencana. Banyak penduduk yang kehilangan mata pencarian selama terjadi bencana. Kedua, kerentanan dalam bidang teknologi. Terdapat perbedaan akses terhadap teknologi antara level kelompok masyarakat. Antara kelompok kaya dan miskin, kelompok masyarakat yang tinggal dikota dan dipedesaan, negara kaya dan negara miskin, kelompok elit dan non elit. Keempat, adanya kemunduran atau ketertinggalan, yaitu kerentanan terhadap kemungkinan timbulnya keadaan yang membuat masyarakat menjadi tertinggal dan harus membangun kembali kehidupannya. Hal ini memerlukam bantuan dari institusi seperti pemerintah dan bantuan dana. Keempat, perpindahan penduduk atau masyarakat yang sebelumnya tidak memiliki pengalaman terhadap tanda-tanda bahaya akan menimbulkan generasi baru yang rentan (newly-generated vulnerabilities). Kelima, kerentanan yang muncul sebagai akibat dari keputusan untuk menolak norma-norma, aturan dan regulasi yang dianggap aman. Pada akhirnya, secara keseluruhan kondisi kerentanan muncul pada peristiwa bencana yang sering hadir dan dianggap sebagai bukan hal yang penting yang sebenarnya menciptakan kondisi bahaya dalam kehidupan secara umum. Uraian Sorensen dan Mileti dalam Sorensen dan kawankawan (2006:213) mengelompokkan tahapan bagaimana penduduk diwilayah rawan bencana merespon peringatan bahaya bencana sebagai berikut: a) mendengar adanya peringatan bahaya bencana. b) memahami isi pesan peringatan bahaya bencana. c) percaya pada peringatan yang dapat dipercaya dan akurat. d) memahami peringatan bahaya bencana untuk diri sendiri. e) mengkonfirmasi bahwa peringatan bahaya bencana benar dan yang lain diabaikan. f) melakukan tindakan perlindungan.

Beaudoin memberikan catatan tentang pentingnya komunikasi dan modal sosial didalam menghadapi bencana alam. 
Karena didalam bencana terdapat unsur ketidakpastian sehingga masyarakat membutuhkan informasi untuk mengetahui apa yang terjadi, memecah ketidak pastian dan membuat keputusan untuk bertahan hidup (Birowo \& Pramono, 2012). Hal ini juga tercantum UU No. 24 tahun 2007 tentang Penanggulangan Bencana pada pasal 12 butir c yang menyebutkan bahwa Badan Nasional Penanggulangan Bencana mempunyai tugas menyampaikan informasi kegiatan kepada masyarakat.

Permasalahan komunikasi dalam situasi menghadapi bencana dikemukakan oleh Mercer dan kawan-kawan dalam Tekauchi dan lain-lain (2009:124) yang menguraikan hasil penelitian Cronin di Ambae Island, Vanuatu. Penelitiannya menggambarkan bagaimana tanda-tanda tentang ancaman bahaya bencana vulkanik yang dituangkan dalam peta ternyata tidak dapat dipahami oleh masyarakat lokal. Masyarakat sebagai komunitas lokal memiliki persepsi berbeda dengan dengan pihak pembuat peta. Sehingga seharusnya alat-alat komunikasi yang dibangun dalam upaya pengurangan resiko bencana dibuat dengan kerjasama antara masyarakat lokal dan konsultan yang memahami masyarakat setempat agar dapat memberikan manfaat. Mercer menyimpulkan bahwa untuk mencapai komunikasi yang efektif dan berkelanjutan dalam rangka membangun strategi pengurangan bencana perlu diupayakan untuk membangun cara komunikasi yang memadai dengan menggunakan metode tertentu agar terjalin kerjasama antar ilmuan dengan masyarakat setempat.

Kesimpulan dari penelitian Setyarto (2012) tentang komunikasi pada peristiwa bencana letusan gunung Merapi tahun 2010 menyebutkan bahwa beberapa istilah yang digunakan pemerintah dalam mitigasi bencana ternyata tidak dikenal oleh masyarakat. Antara lain seperti istilah resiko. Masyarakat setempat lebih akrab dengan istilah dampaknya seperti korban, kehilangan, kerusakan dan sebagainya. Istilah mengungsi lebih dikenal dari pada evakuasi. Selain itu Istyarto juga menyarankan agar pengetahuan lokal dan science dapat bekerjasama menjadi "bahasa" pengungkapan suatu kebenaran tandatanda terjadinya erupsi. Terkait dengan pengetahuan lokal masyarakat mengenai bencana hal ini juga diuraikan dalam temuan hasil penelitian Kusumaningtyas (2007) bahwa masyarakat memahami bencana berasal dari dongeng rakyat atau cerita turun temurun. Didalam keempat cerita rakyat yang diteliti (asal usul upacara Kasada di Gunung Bromo, Jawa Timur, Mad-mado di Nias,legenda kisah Atu Belah di Tanah Gayo Sumatera Utara dan Bujang Munang dari Nanga Serawai Kalimantan Barat) diperoleh temuan tentang pemahaman masyarakat lokal terhadap penyebab timbulnya bencana dan bagaimana cara mengatasinya.

Di jaman informasi dan teknologi yang telah berkembang pesat ini akses informasi juga merupakan media yang tepat untuk menunjang keseimbangan alam. Sikap waspada terhadap kemungkinan terjadinya bencana alam didukung dengan penyebaran dan akses informasi yang memadai merupakan salah satu pemberian ruang kepada bencana untuk terjadi tanpa harus melukai dan mengorbankan manusia (Kusumaningtyas, 2007:14).

Permasalahan komunikasi dalam situasi menghadapi bencana dikemukakan oleh Mercer dan kawan-kawan (2009:124) yang menguraikan hasil penelitian Cronin di Ambae Island, Vanuatu. Penelitiannya menggambarkan bagaimana tanda-tanda tentang ancaman bahaya bencana vulkanik yang dituangkan dalam peta ternyata tidak dapat dipahami oleh masyarakat lokal. Masyarakat sebagai komunitas lokal memiliki persepsi berbeda dengan dengan pihak pembuat peta. Sehingga seharusnya alat-alat komunikasi yang dibangun dalam 
upaya pengurangan resiko bencana dibuat dengan kerjasama antara masyarakat lokal dan konsultan yang memahami masyarakat setempat sehingga dapat memberikan manfaat. Mercer menyimpulkan bahwa diperlukan suatu kajian untuk mencapai

komunikasi yang efektif dan berkelanjutan. Disisi lain dalam rangka membangun strategi pengurangan bencana perlu diupayakan untuk membangun cara komunikasi yang memadai dengan menggunakan metode tertentu agar terjalin kerjasama antar ilmuan dengan masyarakat setempat.

Pada Undang-Undang Republik Indonesia No. 24 Tahun 2007 tentang Penanggulangan Bencana pada pasal pasal 26 diantaranya disebutkan bahwa setiap orang berhak untuk mendapatkan informasi secara tertulis dan atau lisan tentang kebijakan penanggulangan bencana dan pada bagian berikutnya disebutkan bahwa setiap orang berhak untuk berpartisipasi dalam pengambilan keputusan terhadap kegiatan penanggulangan bencana, khususnya yang berkaitan dengan diri dan komunitasnya. Selain itu terkait dengan komunikasi dalam mitigasi bencana dalam pasal 27 juga tercantum bahwa setiap orang berkewajiban untuk memberikan informasi yang benar kepada publik tentang penanggulangan bencana. Sedangkan dalam Pasal 21 dicantumkan bahwa Badan Penanggulangan Bencana Daerah mempunyai tugas: menyusun, menetapkan, dan menginformasikan peta rawan bencana dan pada bagian lain disebutkan bahwa tugas lainnya adalah melaporkan penyelenggaraan penanggulangan bencana kepada kepala daerah setiap sebulan sekali dalam kondisi normal dan setiap saat dalam kondisi darurat bencana. Dari uraian tersebut diatas dan dari penelitian penelitian tentang bencana yang ada maka peneliti menganggap bahwa kajian mengenai komunikasi masyarakat di wilayah bencana masih belum memadai.
Terutama penelitian mengenai perubahan komunikasi masyarakat sebagai bentuk pengetahuan baru atau inovasi dalam mitigasi bencana terutama pada wilayah yang memiliki siklus bencana rutin. Sehingga penting untuk dilakukan kajian mengenai perubahan komunikasi masyarakat diwilayah rawan bencana.

\section{Konsep Difusi Inovasi}

Inovasi memberikan berbagai kemungkinan sebuah alternatif baru atau beberapa alternatif bagi individu atau organisasi sebagai salah satu alat untuk membantu memecahkan masalah. Dalam mitigasi bencana permasalahan yang begitu kompleks muncul dan perlu memperoleh pemecahan. Masalah muncul dari mulai situasi adanya potensi bencana atau pada fase kesiapsiagaan bencana, tahap terjadinya bencana atau tanggap darurat, tahap pemulihan atau recovery hingga pada fase normal dimana belum ada potensi terjadinya bencana.

Difusi adalah proses dimana inovasi dikomunikasikan melalui beberapa saluran yang dilakukan sepanjang waktu diantara anggota-anggota dalam sistem sosial (Rogers, 1995:10). Sehingga terdapat empat elemen penting di dalam difusi yaitu inovasi, saluran komunikasi, waktu dan sistem sosial. Adapun uraian masingmasing elemen adalah sebagai berikut: Pertama, Inovasi, bisa merupakan suatu ide, kegiatan praktis atau objek yang dipahami sebagai sesuatu yang baru oleh individu atau unit yang mengadopsi. Kebaruan dari suatu ide bagi individu maka disebut sebagai inovasi. Kebaruan dari inovasi bukan hanya dapat dilihat dari pengetahuannya, namun dapat ditinjau dari elemen persuasinya dan keputusan untuk mengadopsi inovasi.

Selain itu inovasi sendiri memiliki lima karakteristik tertentu yang dapat dipahami oleh individu yang dapat menjelaskan perbedaan kecepatan dalam 
mengadopsinya. Karakteristik tersebut adalah pertama yaitu relative advantage, adalah tingkat pemahaman bahwa inovasi yang diperoleh lebih baik dan dapat menggantikan ide sebelumnya. Karakteristik compatibiliy adalah tingkat pemahaman tentang inovasi sebagai sesuatu yang dapat konsisten dengan nilai-nilai yang telah ada sebelumnya, dengan pengalaman-pengalaman masa lalu dan adanya kebutuhan untuk mengadopsi inovasi. Pada karakteristik berikutnya yaitu complexity, adalah tingkat pemahaman sejauh mana inovasi baru dianggap memiliki tingkat kesulitan untuk dimengerti dan digunakan. Karakteritik keempat adalah trialability adalah tingkat pemahaman tentang inovasi yang dilakukan uji coba dalam batas tertentu. Uji coba ini memperkecil resiko ketidakpastian bagi inovasi untuk diadopsi. Karakteristik kelima dari inovasi adalah adalah observability. Adalah seberapa besar peluang inovasi yang telah diadopsi dapat dilihat oleh orang lain. Ketika banyak pihak lain yang melihat bahwa inovasi yang telah diadopsi memberikan hasil maka orang lain akan mudah mengikutinya. Kedua, Saluran Komunikasi. Dalam konsep difusi inovasi komunikasi didefinisikan sebagai proses dimana para peserta menghasilkan dan berbagi informasi antara satu dengan yang lain untuk mencapai saling pemahaman. Difusi merupakan salah satu tipe komunikasi dimana isi pesan yang dipertukarkan fokusnya adalah tentang ideide baru. Ketiga, Waktu. Elemen waktu dalam konsep difusi inovasi terkait dengan proses difusi. Pada beberapa riset tentang perubahan perilaku unsur waktu bahkan sering di abaikan. Namun pada beberapa penelitian tentang difusi waktu merupakan kekuatan dari terjadinya difusi. Dimensi waktu adalah merupakan bagian dari difusi dalam hal: 1) proses keputusan inovasi dimana individu melalui tahapan dari pengetahuan awal mengenai inovasi sampai kepada adopsi atau penolakan. 2) Dalam proses adopsi inovasi perlu diperhatikan kecepatandan kelambatan individu atau unit dalam mengadopsi inovasi dibandingkan dengan anggota lainnya. 3) Untuk proses tingkat kemampuan mengadopsi inovasi, ukuran dari jumlah anggota dalam satu sistem yang mampu mengadopsi inovasi diukur dalam periode waktu.

Uraian Rogers dan Kincaid bahwa hampir semua penelitian tentang difusi inovasi pada masa lalu berbasikan pada model komunikasi linear dimana proses pesan mengalir dari sumber ke penerima pesan. Seperti halnya komunikasi satu arah yang merupakan tipe tertentu dari komunikasi. Berbagai bentuk difusi dilakukan secara konsisten seorang individu yang merupakan agen perubahan dalam menginformasikan ide baru kepada calon adopter yang potensial. Namun demikian bentuk lain dari difusi digambarkan secara lebih akurat dengan model konvergeni, dimana komunikasi didefinisikan sebagai sebuah proses dimana partisipan menghasilkan dan membagi informasi dengan pihak lain untuk mencapai saling pengertian. Sehingga pada kajian yang ada saat ini tercapai sebuah konsep tentang difusi menggunakan model konvergensi ddengan menekankan adanya pertukaran informasi diantara partisipan dalam proses komunikasinya. (Rogers, 1995:XVI).

\section{Konsep Informasi}

Dari perspektif sejarah, terdapat beberapa pengertian tentang informasi yang diantaranya dikemukakan oleh Shanon (Ritchie, 1991:6-8) yang memandang informasi dari terminologi mekanik. Komunikasi antar manusia memiliki elemenelemen seperti sinyal, transmisi, encoding dan decoding. Sementara Weaver mengembangkan konsep tersebut dengan menekankan bahwa perlu ditambahkan 
elemen mengenai arti dari informasi dan bagaimana informasi dapat berjalan dengan efektif. Sehingga komunikasi bukan hanya sekedar transmisi secara fisik. Pada konsep yang dikemukakan Shanon pemahaman informasi menjadi kurang lengkap karena makna informasi tidak terpenuhi sehingga dibutuhkan elemen lain yaitu bagimana informasi dapat memberikan arti dan dapat berjalan efektif seperti yang dikehendaki oleh pengirim pesan.

Konsep lain tentang informasi menyebutkan bahwa informasi dapat dianggap sebagai sejumlah pilihan atau alternatif yang digunakan untuk memprediksi suatu hasil. Dalam situasi yang kompleks dengan berbagai macam kemungkinan hasil, informasi lebih banyak tersedia dibandingkan dengan pada situasi yang sederhana dan dengan kemungkinan hasil yang lebih sedikit. Semakin banyak informasi yang dimiliki maka, maka kemungkinan alternatif yang diperoleh akan semakin banyak (LittleJohn \& Foss,2002: 42). Sehingga dalam konsep transmisi informasi, fokus kajiannya bukan mengenai arti dari sebuah informasi namun hanya terfokus pada bagaimana informasi dipindahkan dan diterima, dan informasi akan membantu dalam mengurangi ketidakpastian. Pada uraian selanjutnya dijelaskan bahwa sikap seseorang dipengaruhi oleh dua variable yaitu arah kecenderungan (valence) dan bobot nilai (weight) terhadap informasi. Arah kecenderungan ini akan menentukan bagaimana sikap seseorang dalam menerima informasi yang diperoleh terhadap kepercayaannya. Jika informasi yang diperoleh mendukung kepercayaan seseorang, maka sikapnya akan positif dan sebaliknya jika informasi yang diperoleh bertentangan dengan kepercayaannya maka informasi akan ditolak. Pada variable kedua yaitu mengenai bobot (weight) terhadap informasi, hal ini terkait dengan fungsi kredibilitas terhadap informasi. Jika informasi yang diterima dianggap benar maka akan menambah nilai sikap seseorang terhadap kepercayaannya. Sebaliknya jika informasi yang diterima dianggap salah maka akan menurunkan bobot penilaian terhadap kepercayaan seseorang mengenai sesuatu hal. Sehingga dapat disimpulkan bahwa unsur arah kecenderungan (valence) menentukan bagaimana (how) arah sikap sesorang terhadap sesuatu). Sedangkan bobot nilai (weight) menentukan seberapa besar (how much) sikap seseorang terhadap sesuatu.

Konsep Information-Integration yang dikemukakan oleh Leandre ini melengkapi fungsi informasi dari konsep yang dikemukakan sebelumnya dengan pendekatan oleh Shanon dan Weaver yang lebih cenderung menjelaskan tentang elemen-elemen informasi dan bagaimana informasi dapat memberikan arti. Karena dari konsep Information-Integration, dapat disimpulkan bahwa upaya seseorang untuk memperkuat keyakinannya tentang sesuatu yang dapat dilakukan dengan mengumpulkan berbagai informasi yang saling terkait. Proses tersebut memberikan arah untuk semakin meyakini atas informasi yang diperoleh atau justru mengurangi keyakinannya terhadap sesuatu akibat dari informasi yang diperoleh. Demikian pentingnya informasi dalam kajian komunikasi karena dengan ketentuan informasi terdapat perbedaan yang signifikan ketika harus menentukan pilihan dari beberapa alternatif yang ada. Peluang untuk mengurangi ketidakpastian ketika seseorang harus menentukan pilihan atau mengambil keputusan dapat dilakukan dengan permrosesan informasi (Rogers dan Kincaid,1981:48). Hal ini dapat dijelaskan antara lain ketika seseorang harus menentukan pilihan dari berbagai alternatif yang ada seringkali keputusan dapat diambil setelah adanya informasi. Bahkan keputusan dapat berubah atau berbeda hanya karena adanya informasi yang membedakan antara alternatif yang satu dengan alternatif yang 
lain. Sehingga uraian Bateson dalam Rogers dan Kincaid (1981:49) menegaskan penjelasan sebelumnya bahwa perbedaan dapat terjadi karena adanya informasi. Penjelasan yang dapat disimpulkan dari Bateson adalah bahwa informasi menciptakan perbedaan mengenai seuatu hal. Seseorang memiliki sikap yang berbeda dari orang lain atau mengambil keputusan yang berbeda adalah karena ketersediaan informasi atau dari informasi yang diperoleh. Pada tahap selanjutnya argumentasi ini memberikan penjelasan yang lebih luas bahwa dengan informasi dapat mengurangi ketidakpastian sesuai dengan terminologi berikut yang dikemukakan oleh Pearson \& Nelson dalam Ritchie (1991:3). Konsep informasi dalam komunikasi merupakan terminologi untuk menjawab pertanyaan dan mengurangi ketidakpastian. Sementara teori pengurangan ketidakpastian (uncertainty reduction) yang dikemukakan oleh Berger dan Calabrese dalam Miller (2005:176) cakupan dan tujuannya meliputi bentuk model proses interaksi dalam pengembangan relasi. Dalam teori tersebut Berger dan Calabrese menyebutkan bahwa teori ini menggunakan asumsi bahwa setiap orang ketika berelasi dengan orang lain yang masih asing didorong oleh keinginan untuk mengurangi ketidakpastian diantara satu sama lain.Unsur ketidakpastian tersebut meliputi kognitif dan perilaku. Ketidakpastian dari segi kognitif adalah pada unsur kepercayaan dan sikap satu sama lain. Sedangkan ketidakpastian dalam hal perilaku adalah bagaimana orang lain akan bertindak dalam interaksi satu sama lain. Pengembangan dari teori ini dilakukan oleh Berger yang memberikan perhatian pada konsep tentang strategi untuk memperoleh informasi dalam rangka mengurangi ketidakpastian.

Dalam pandangan peneliti dalam mencapai penyebaran informasi yang optimal maka diperlukan peran opinion leader yang dapat menularkan informasi kepada kelompok. Peran opinion leader dalam penularan informasi merupakan salah satu elemen dalam proses integrasi informasi seperti tentang kredibiltas seseorang, maupun posisi opinion leader sebagai pihak yang informasinya dapat menambah keyakinan penerima informasi mengenai sesuatu hal yang telah diketahu sebelumnya.

Salah satu elemen dalam konsep komunikasi adalah mengenai informasi yang dikemukakan oleh Chafee (1991:3). Disebutkan oleh Chafee mengutip penjelasan dari Dooglas bahwa informasi termasuk didalamnya adalah data, pengetahuan dan opini. Selain itu informasi juga digunakan untuk menjawab pertanyaan dan mengurangi ketidakpastian, sehingga informasi harus memiliki keterkaitan antara sesuatu yang tidak diketahui dengan sesuatu yang sudah diketahui sebelumnya.

\section{Bencana dan Mitigasi Bencana}

Menurut Undang-undang Republik Indonesia No.24 Tahun 2007 Tentang Penanggulangan Bencana pada pasal 1 diuraikan bahwa bencana adalah peristiwa atau rangkaian peristiwa yang mengancam dan mengganggu kehidupan dan penghidupan masyarakat yang disebabkan, baik oleh faktor alam dan atau faktor non alam maupun faktor manusia sehingga mengakibatkan timbulnya korban jiwa manusia, kerusakan lingkungan, kerugian harta benda, dan dampak psikologis. Selanjutnya pada pasal 2 disebutkan bahwa bencana alam adalah bencana yang diakibatkan oleh peristiwa atau serangkaian peristiwa yang disebabkan oleh alam antara lain berupa gempa bumi, tsunami, gunung meletus, banjir, kekeringan, angin topan, dan tanah longsor.

Penanggulangan Bencana pada pasal 1 diuraikan bahwa bencana adalah peristiwa atau rangkaian peristiwa yang mengancam dan mengganggu kehidupan dan penghidupan masyarakat yang disebabkan, 
baik oleh faktor alam dan atau faktor non alam maupun faktor manusia sehingga mengakibatkan timbulnya korban jiwa manusia, kerusakan lingkungan, kerugian harta benda, dan dampak psikologis. Selanjutnya pada pasal 2 disebutkan bahwa bencana alam adalah bencana yang diakibatkan oleh peristiwa atau serangkaian peristiwa yang disebabkan oleh alam antara lain berupa gempa bumi, tsunami, gunung meletus, banjir, kekeringan, angin topan, dan tanah longsor. Dalam Undang-undang tersebut pada ketentuan umum butir 9 tercantum bahwa mitigasi adalah serangkaian upaya untuk mengurangi risiko bencana, baik melalui pembangunan fisik maupun penyadaran dan peningkatan kemampuan menghadapi ancaman bencana.

Sylves (2008:21) mengemukakan bahwa dalam mitigasi tercakup keputusan untuk melakukan apa dan dimana terkait masalah kesehatan, keamanan dan kesejahteraan dari masyarakat yang telah ditentukan dan dilaksanakan sebagai program pengurangan resiko. Hal ini merupakan tindakan yang berkelanjutan untuk mengurangi resiko terhadap jiwa dan harta benda serta dampaknya. Berikutnya hal lain yang penting terkait dengan mitigasi adalah perhitungan efektifitas biaya yang dikeluarkan dengan pengurangan resiko yang akan terjadi termasuk kemungkinan resiko fisik dan sosial dimasa yang akan datang.

Claude Gilbert menyodorkan ringkasan konsep tentang bencana (Porfiriev in Quarantelli, 1998:58) dalam tiga paradigma yaitu. Pertama, bencana adalah merupakan hasil atau akibat dari suatu tekanan eksternal. Kedua, akibat dari kerentanan sosial dan ketiga akibat dari ketidakpastian. Konsep ini masih senada dengan Pelanda yang dikutip dari sumber yang sama yang mengintepretasikan bencana sebagai berikut. Pertama, bencana adalah akibat dari kondisi sosial dan lingkungan yang buruk, Kedua, bencana merupakan akibat dari tekanan kolektif dari sebuah komunitas, dan Ketiga adalah adanya perbedaan dalam kapasitas untuk menangani kerusakan dan akibat negatif yang ditimbulkan. Hal yang perlu dicermati terkait dengan berbagai definisi mengenai bencana adalah perspektif yang digunakan dalam melihat bencana. Berikut adalah salah satu definisi bencana dari dari Webster's New World Dictionary of The American Language yang dikutip oleh Porfiriev dalam Quarantelli (1998:57).

"..any happening that causes great harm or damage; serious or sidden misfortune;calamity. Disaster implies great or sudden misfortune that results in loss of life, property, etc. or that in ruinous to an undertaking; calamity suggests a grave misfortune that brings deep distress or sorrow to an individual or to the people at large." Dahl's Tolkovi Slovar Zhivogo Velikorusskogo Yazika (Explanatory Dictionary of The Great Russian Living Language) :

"Beda (misfortune) or bedstviye (disaster) is an incident, accident or other harmful occasion resulting in losses and sorrow. Disaster is more related to known cases of crop failure, epidemic, storms, flodds, To suffer disaster means being a disastrous or dangerous situation;badly needing something; dying."

Dari kedua sumber tersebut disebutkan bahwa bencana merupakan peristiwa yang mengakibatkan kerusakan, kematian, kehilangan dan dampak buruk lainnya termasuk beberapa jenis peristiwa alam yang dianggap menimbulkan bencana.

Pendapat lain dikemukakan oleh Maloney dan Cappola (2009:48-49) tentang bencana:

"Disaster are measured in terms of lives lost, injuries, sustained, property damaged or lost, and environment degradation. These consequences manifest themselves through direct and indirect means and can be tangible or intangible."

Beberapa ahli sosial menekankan 
pemahaman tentang bencana sebagai sebuah konstruksi sosial. Bagi para ahli tersebut melihat bencana sebagai dampak dari proses soasial atau konsekuensi sosial yang menghasilkan bahaya, atau meningkatkan kerentanan dari sebuah sistem sosial dari dampak suatu bahaya (Porfiriev in Quarantelli,1998:59). Selanjutnya dari kajian konsep dan pragmatis tentang bencana Quarantelli mencoba memberikan defisinya mengenai bencana sebagai berikut:

"a state/condition destabilizing the social system that manifest itself in malfunctioning or disruption of connection and communications between its elements or social units (communities, social groups, and individuals), partial or total detruction/demolition, physical and psychological overload suffered by some of these elements; thus, making it necessary to take extraordinary or emergency countermeasures to reestablish stability."

Sementara dari kajian tentang di wilayah bencana berikut penanganannya dapat dibagi menjadi dua bagian (Porifiev dalam Quarantelli,1998:65-67) yaitu: 1. Emergency or acute disaster area, bencana yang dipicu oleh kejadian alam, teknologi, sosialpolitik, banjir, gempa bumi, tornado, badai, gunung meletus, kebakaran dan sebagainya. Tindakan dalam penanganan bencana ini termasuk kategori urgent (extraordinary) short term action, yaitu tindakan segera dalam penanganan bencana. Selain itu juga terkait dengan tindakan terhadap bencana yang bersifat kronis. 2. Chronic disaster areas atau biasanya disebut sebagai area bencana yang memiliki akibat dalam jangka yang panjang seperti misalnya bencana kelaparan, kontaminasi radio aktif pada lingkungan dan sebagainya. Tindakan penanganan dalam bencana jenis ini adalah medium and long tem action. Biasanya terdapat wilayah bencana susulan atau terjadi di wilayah lain yang berikutnya sebagai dampak dari bencana sebelumnya.

Pentingnya informasi bagi masyarakat mengenai bencana juga dikemukakan Malloney dan Capola (2009:18):

"Once an audience is informed sufficiently and appropriately about a hazard, they are primed to receive and process information that will help them take appropriate action to reduce their vulnerability to one or more hazard risk."

Menurut konsep tersebut, tujuan akhir dari manajemen penanganan bencana adalah peringatan dini bagi masyarakat. Peringatan dini membuat masyarakat menjadi lebih waspada dan tersedianya informasi resmi untuk kemudian mengambil tindakan yang tepat. Pesan tentang peringatan dini dibangun untuk mentransmisikan pesan kepada semua pihak di manapun dan kapanpun. Dengan menggunakan berbagai macam sistem, dan kolaborasi antara masyarakat, pemerintah, lembaga non pemerintah, pihak swasta akan meningkatkan kemampuan sistem komunikasi dalam mencapai target sasaran masyarakat.

Berikutnya terkait dengan edukasi kepada masyarakat maka terdapat beberapa syarat agar informasi tentang penanganan bencana dapat diterima masyarakat dengan efektif. 1) Perlu adanya kepercayaan masyarakat terhadap pihak yang menyampaikan pesan (trustworthy). 2) (authoritative) pihak yang menyampaikan pesan adalah pihak yang dianggap memiliki kewenangan atau kualifikasi sebagai pengirim informasi, karena setiap individu bebas untuk memilih siapa pihak yang ingin didengarnya. 3) Tidak adanya kepentingan untuk memperoleh sesuatu dari informasi yang disampaikan. Masyarakat harus merasa yakin bahwa informasi yang diperoleh tidak memiliki kepentingan tertentu (free of personal gain). 4) Informasi yang disampaikan hendaknya akurat, dapat dikonfirmasi bahkan dapat didukung oleh data-data. 5) konsistensi dalam penyampaian pesan, terutama pesan yang disampaikan secara berulang. Pesan yang 
disampaikan melalui media yang berbeda seperti radio, cetak, internet berisi konten yang sama. 6) Pesan disampaikan berulangulang untuk memberikan pemahaman bagi masyarakat (repetitive). 7) Pesan hendaknya mudah dipahami (easily understood) dengan mempertimbangkan faktor-faktor seperti istilah yang sering dipahami masyarakat setempat, tingkat pendidikan, faktor geografi dan sebagainya. 8) Agar pesan mudah diterima, perlu dipertimbangkan faktor rasionalitasnya. Informasi disampaikan secara konkret misalnya mengenai area yang terdampak, rentang waktu kerawanan bencana dan sebagainya. 9) Informasi hendaknya mudah diakses oleh semua orang. 10) Informasi yang disampaikan hendaknya juga memberikan solusi bagi masyarakat sehingga komunikasi berlangsung efektif.

Selanjutnya Carter membagi bencana dalam 5 segmen yaitu : Prevention, Mitigation, Preparedness, Response dan Recovery. Pada segmen awal yaitu pencegahan (prevention), fokus perhatiannya adalah pada hal-hal akan mengenai pentingnya upaya pencegahan, wilayah yang perlu menjadi perhatian untuk dilakukan pencegahan, pendekatan yang positif melalui upaya pencegahan dan sumberdaya apa saja yang diperlukan untuk pencegahan. Pada segmen Mitigasi (Mitigation), tindakan yang dilakukan biasanya merupakan program yang spesifik untuk mengurangi dampak dari bencana pada suatu bangsa atau komunitas. Pemahaman tentang mitigasi lebih luas adalah implikasi dampak dari bencana, namun demikian dampak tersebut dapat dimodifikasi atau dikurangi dengan tindakan yang sesuai. Beberapa tindakan atau program terkait dengan mitigasi antara lain: regulasi pemanfaatan wilayah, regulasi tentang keamanan untuk bangunan tinggi, kontrol terhadap materi hazard, keamanan sistem transportasi darat, laut dan udara; pembangunan sistem untuk melindungi instalasi listrik dan alat komunikasi vital, pembangunan infrastruktur seperti misalnya pembangunan jalan bebas hambatan yang tidak berdekatan dengan wilayah rawan bencana. Segmen ketiga adalah kesiapsiagaan (Preparedness). Pada fase ini terdapat beberapa hal penting yang diperlukan sebagai upaya peringatan dini yaitu: deteksi dini yang dilakukan seawall mungkin tentang akan datangnya bencana, proses peringatan dini yang harus dilakukan oleh pihak yang memiliki wewenang sehingga menghindari informasi yang tidak perlu, adanya rantai transmisi informasi yang efektif, pengambilan keputusan setelah adanya peringatan dini, dan penyebaran informasi peringatan dini ke publik secara tepat. Dari banyak pengalaman mitigasi bencana reaksi awal terhadap peringatan dini bencana dapat menyelamatkan nyawa dan harta benda. Pada periode tanggap darurat (response) ini aspek emergensi yang perlu diperhatikan pada fase tanggap darurat adalah : A)penyelamatan dan pertolongan terhadap korban. B)pengungsian korban ke wilayah lain. C)penyediaan tempat penampungan sementara yang layak. D) Penyediaan makan, baik distribusi dan persediaan stok bahan pangan. E)pembukaan akses jalan melalui darat udara atau laut termasuk pendaratan helikopter. F)ketersediaan alat komunikasi. G) ketersediaan air bersih. $\mathrm{H})$ ketersedian barang - barang kebutuhan untuk pengungsi. I) sarana kesehatan dan sanitasi, tenaga medis. J) ketersediaan informasi publik. Tersedianya informasi bagi komunitas tentang apa yang harus dilakukan. K)Jaminan keamanan konstruksi untuk bangunan yang mendapatkan prioritas tertinggi 1)jaminan untuk dukungan moral bagi korban.

Segmen recovery, merupakan proses pemulihan yang dapat berlangsung lama bahkan bisa mencapai waktu antara 5-10 tahun atau lebih. Pemulihan pasca bencana biasanya melibatkan berbagai aspek sperti 
restorasi dan rekonstruksi. Dalam melaksanakan program pemulihan pasca bencana keterlibatan berbagai institusi sangat diperlukan antara lain seperti pemerintah yang memiliki otoritas dalam hal perencanaan membangun maupun pemerintah yang menangani bencana baik pusat maupun lokal termasuk institusi yang menyediakan pendanaan. (Carter, 2008:240288).

\section{Metode Penelitian}

Jenis penelitian ini adalah kualitatif deskriptif, dengan objek penelitian masyarakat di dusun Kalitengahkidul, Desa Glagahharjo, Sleman Daerah Istimewa Yogyakarta. Pengumpulan data dilakukan dengan observasi dan wawancara. Observasi dilakukan terhadap lingkungan tempat tinggal masyarakat, pengamatan terhadap papan-papan petunjuk mitigasi bencana seperti: panduan evakuasi, lokasi tempat warga berkumpul dalam kondisi siaga, lokasi hunian sementara, jalur evakuasi, lokasi menara pemantau aktivitas gunung dan sebagainya. Wawancara dilakukan kepada enam orang penduduk setempat dengan kriteria informan yang dipilih adalah penduduk yang telah tinggal diwilayah tersebut selama lebih dari dua puluh tahun sehingga sempat mengalami beberapa peristiwa aktivitas gunung Merapi. Validasi data dilakukan dengan melakukan wawancara kepada kepala dusun serta dengan mempelajari dokumendokumen yang relevan seperti panduan tertulis mengenai mitigasi bencana yang disusun oleh warga.

Analisa data dilakukan dengan melakukan koding terhadap hasil wawancara kemudian dilakukan analisa serta intepretasi hasil wawancara serta observasi dengan menggunakan konsepkonsep komunikasi. Keabsahan data dilakukan dengan proses triangulasi yaitu dari hasil wawancara dengan informan masyarakat dan observasi lapangan dilakukan konfirmasi dengan kepala dusun, ketua $R T$, relawan dan dengan menggunakan konsep-konsep tentang mitigasi bencana. Dari proses ini diperoleh gambaran yang utuh mengenai hasil wawancara dengan informan.

\section{Hasil Penelitian dan Pembahasan}

Dusun Kalitengah Kidul merupakan salah satu dari 10 Dusun diwilayah Desa Galagahharjo, Kabupaten Sleman Daerah Istimewa Yogyakarta. Batas wilayah dusun Kaltengah Kidul dibagian selatan berbatasan dengan dusun Srunen, disebelah barat dengan Sungai Gendol, Disebelah Utara dengan dusun Kalitengah Wetan dan disebelah Timur dengan Daerah Istimewa Yogyakarta. Dusun Kalitengahkidul terdiri dari 4 RT dengan jumlah kepala keluarga sebanyak 109 dan jumlah warga 315 orang. Alasan pemilihan desa ini adalah karena selain desa ini terdekat dengan puncak Merapi $(+/-5 \mathrm{~km})$ pada erupsi gunung berapi Merapi tahun 2010 desa ini merupakan salah satu dari tiga wilayah di Kabupaten Sleman yang terparah dilanda bencana. Letusan Merapi pada tahun 2010 kekuatannya sekitar 4 VEI (Volcanic Explosivity Index, pada skala 8), dengan mengeluarkan 140 juta meter kubik material vulkanik.

Perubahan Komunikasi Masyarakat Sebelum dan Setelah Erupsi Tahun 2010.

\section{Inovasi}

Dalam penelitian ini inovasi adalah berbagai informasi baru mengenai mitigasi bencana. Antara lain adalah cara mengetahui informasi akan tanda - tanda potensi aktivitas gunung, siapa pihak yang dapat diandalkan untuk mengetahui status gunung. Informasi mengenai kapan harus mengungsi, kemana arah pengungsian, siapa yang menjadi prioritas untuk mengungsi, alat transportasi apa yang dapat digunakan untuk mengungsi, dokumen 
penting apa saja yang perlu dibawa saat mengungsi, siapa saja pihak yang dihubungi untuk dimintai bantuan.

\section{Saluran Komunikasi}

Beberapa hal penting dan marupakan inovasi baru bagi masyarakat setempat dalam menggunakan saluran informasi untuk mitigasi bencana antara lain adalah penggunaan alat komunikasi handy talkie dalam jumlah yang lebih banyak, pemanfaatan informasi dari data yang diperoleh melalui pemancar yang diterjemahkan dalam bentuk grafik, komunikasi kelompok, pembuatan standar operasional bencana, pembuatan tandatanda petunjuk evakuasi di beberapa wilayah strategis.

\section{Waktu}

Peristiwa erupsi gunung Merapi pada tahun 2010 adalah waktu yang menentukan dan bersifat traumatis sehingga proses difusi innovasi dalam mitigasi bencana. Setelah erupsi tahun 2010 kesiapsiagaan bencana mengalami perubahan antara lain dengan adanya kordinasi yang lebih terorganisir, prioritas pengungsian yang lebih jelas tahapannya serta inisiatif warga yang lebih cepat tanggap. Hal ini sesuai dengan uraian Maloney dan Coppola bahwa suatu saat ketika masyarakat memperoleh informasi secara memadai tentang peringatan dini, maka mereka akan menerima dan memroses informasi yang akan membantu mereka mengambil tindakan yang tepat untuk mengurangi resiko dalam menghadapi bencana.

Dibandingkan erupsi pada tahun 2006 dimana masyarakat menganggap bahwa pengetahuan yang mereka percaya selama ini tentang perilaku Merapi, maka informasi dan kebiasaan lama masih dapat diandalkan. Sehingga atas dasar pengalaman dengan menggunakan pengamatan visual, kebiasaan, dan kepercayaan yang selama ini dianut dianggap cukup. Selain itu pada tahun 2006 aktivitas gunung pun tidak menyebabkan masyarakat sampai harus mengungsi. Namun dahsyatnya erupsi Merapi tahun 2010 memberikan banyak perubahan terhadap pengetahuan, sikap dan tindakan masyarakat dalam mengadopsi inovasi baru dalam mitigasi bencana.

Setelah peristiwa bencana merapi pada tahun 2010 masyarakat lebih menyiapkan diri menghadapi bencana dengan memiliki alat komunikasi HT (handy talkie) dengan jumlah yang lebih banyak untuk setiap kelompok warga, rata-rata memiliki alat trasnportasi sepeda motor.

Sebelum bencana erupsi tahun 2010 hanya sedikit warga yang memiliki alat komunikasi HT, dan alat trasportasi. Pengalaman traumatik pada bencana erupsi tahun 2010 membuat penduduk mememiliki kewaspadaan yang lebih tinggi serta sensitifitas yang lebih besar dalam menghadapi tanda-tanda bencana.

Sebelum peristiwa erupsi tahun 2010 masyarakat setempat cenderung menyangsikan informasi yang disampaikan BPPTK (Balai Penyelidikan dan Pengembangan Teknologi Kegunungapian) mengenai status gunung berapi Merapi karena dalam pengamatan visual penduduk belum ada aktivitas gunung yang membuat mereka harus mengungsi. Sehingga warga cenderung menyangsikan perintah kepala dusun untuk bersiap-siap mengungsi. Kepercayaan masyarakat setempat terhadap aktivitas Merapi yang selama lebih dari 20 tahun tidak mengalami erupsi besar juga turut memperkuat sikap masyarakat dengan tidak langsung mengikuti informasi dari pihak yang berwenang. Perintah mengungsi baru diikuti beberapa hari setelah Merapi mengalami peningkatan aktivitas yang signifikan sehingga warga dengan dibantu relawan dan pemerintah akhirnya mau mengungsi pada saat-saat terakhir menjelang Merapi erupsi. Mekipun korban jiwa yang meninggal kurang dari 10 orang, namun banyak warga yang tidak sempat menyelamatkan harta benda serta 
hewan ternak yang merupakan aset utama untuk membantu memperoleh nafkah sehari-hari. Dengan peristiwa erupsi tahun 2010 yang menimbulkan pengalaman traumatik tersebut memberikan perubahan pemahaman bagi warga bahwa aktivitas merapi tidak hanya dapat dipahami berdasarkan kebiasaan yang dialami selama ini. Bahkan masyarakat saat ini sudah dapat mempercayai bahwa pantauan merapi yang menggunakan teknologi lebih akurat daripada hanya mengandalkan pengamatan perilaku merapi dan pandangan visual.

Meskipun sebagian penduduk sudah memiliki alat komunikasi HT, namun alat komunikasi sirine dan kentongan masih digunakan sebagai alat komunikasi yang diandalkan untuk menyampaikan informasi bahaya bencana. Beberapa rumah penduduk yang terletakjauh dari penduduk lain atau penduduk usia lansia mengandalkan alat komunikasi tersebut karena tidak memiliki HT atau tidak dapat menggunakan HT. Penggunaan handphone (HP) dianggap tidak efektif karena terkendala akses sinyal.

Berikutnya hasil penelitian mengenai perubahan komunikasi masyarakat dalam menghadapi bencana sebelum dan setelah erupsi Merapi tahun 2010, ditampilkan dalam tabel dibawah ini. Keterkaitan dengan dimensi pada konsep difusi inovasi adalah dari bahwa uraian didalam setiap bagian memiliki elemen inovasi dimana terdapat ide-ide baru dalam mitigasi bencana, dan saluran komunikasi yang digunakan sementara elemen waktu terdapat pada pembagian waktu yaitu sebelum tahun 2010 dan setelah tahun 2010.

Tabel 1

Perubahan komunikasi masyarakat dalam menghadapi bencana sebelum dan setelah erupsi Merapi tahun 2010.

\begin{tabular}{lll}
\hline Sebelum Erupsi Tahun 2010 & \multicolumn{3}{c}{ Setelah Er upsi Tahun 2010 } \\
\hline Tidak ada papan petunjuk mengenai jalur & $\begin{array}{l}\text { Terdapat papan petunjuk mengenai jalur } \\
\text { kumpul dan tempat }\end{array}$ \\
evakuasi, lokasi titik kumpul, lokasi waspada & evakuasi, titik $\begin{array}{l}\text { kum } \\
\text { jalur yang dilalui awan panas, lokasi pengungsian, namun bentuk papan belum } \\
\text { waspada jalur yang dilalui lahar dan lokasi } \\
\text { tempat peragam dalam hal ukuran, warna, tulisan. } \\
\text { hunian sementara. }\end{array}$
\end{tabular}

Tidak terdapat panduan tertulis (manual) Sudah terdapat panduan tertulis (manual) bagi bagi warga sebagai managemen informasi warga sebagai managemen informasi kewasapadaan bencana. kewasapadaan bencana yang berisi data-data penduduk serta peta informasi tentang kebencanaan.

Tidak terdapat petunjuk dalam bentuk gambar untuk petunjuk arah evakuasi dilapangan.
Baru ada sedikit petunjuk dalam bentuk gambar tentang kewaspadaan bencana di beberapa titik lokasi ditepi jalan utama. Belum banyak terdapat papan petunjuk di lokasi pelosok atau yang agak terpencil dari jalan utama dusun. 
Sebelum Erupsi Tahun 2010

Sosialisasi mengenai bencana seperti dalam bentuk simulasi jarang dilakukan, jikal aupun ada dilakukan kurang intensif, warga cenderung mengabaikan sosialisasi dari BPPTK.

Tidak ada pertemuan warga secara rutin Terdapat pertemuan secara rutin membahas membahas mengenai kewaspadaan mengenai kewaspadaan menghadapi bencana. menghadapi bencana.
Ada sosialisasi yang terjadwal baik dari kepala dusun maupun pihak BPPTK.

\section{Setelah Erupsi Tahun 2010}

Belum ada kordinasi yang optimal dengan

Sudah dibangun kordinasi antara kelompok kelompok dilingkungan RT dan RW dilingkungan RT dan RW mengenai mengenai masyarakat yang perlu masyarakat yang diprioritaskan dalam diprioritaskan (balita, lansia, kaum difabel) penanganan bencana (orang cacat, lansia, dalam menghadapi bencana. anak-anak, ibu hamil).

Pengambilan keputusan untuk mengungsi tergantung informasi dari kepala dusun dan kelompok tetangga sekitar tempat tinggal.
Mulai dapat mengambil keputusan sendiri untuk mengungsi dengan mengandalkan informasi dari pos pengawas dan BPPTK (Balai Penyelidikan dan Pengembangan Teknologi Kegunungapian).
Keputusan untuk menggunakan alat ransportasi mengungsi menunggu informasi dari kepala dusun atau ketua kelompok.
Warga sudah dapat mengambil keputusan tanpa menunggu informasi dari pihak lain mengenai alat transportasi yang digunakan untuk mengungsi.
Penggunaan HT sebagai alat komunikasi diantara warga sangat minim, untuk berkordinasi dan mengetahui status waspada, hanya kepala dusun yang memiliki
Hampir setiap kelompok warga memiliki HT untuk mengetahui status waspada gunung dan saling berkordinasi pada saat terdapat potensi bencana.

Penggunaan alat komunikasi tradisional Penggunaan al at komunikasi tradisional kentongan dengan memperhatikan nada kentongan masih digunakan, namun untuk tertentu sebagai tanda bahaya. radius tertentu dan bagi masyarakat yang tidak dapat menggunakan HT (kaum lansia). 


\section{Kesimpulan}

Telah terjadi berbagai perubahan pada komunikasi masyarakat diwilayah rawan bencana sejak erupsi Merapi tahun 2010 dibandingkan sebelumnya. Inovasi dalam komunikasi untuk mitigasi bencana membawa perubahan antara lain pada bentuk komunikasi kelompok, alat komunikasi yang digunakan, sikap masyarakat terhadap informasi yang disampaikan oleh pemerintah atau instansi resmi, hingga komunikasi yang menentukan pengambilan keputusan individu dalam proses evakuasi. Namun demikian masih banyak komunikasi yang perlu diperbaiki dan ditingkatkan terait dengan mitigasi bencana.

Pada komunikasi kelompok, masyarakat mengalami perubahan yang semula sangat tergantung dengan informasi dari kelompok disekitar tempat tinggalnya, kini masyarakat aktif mencari informasi sendiri. Jika sebelum erupsi tahun 2010 masyarakat kurang mempercayai informasi dari luar seperti lembaga pemerintah atau relawan, setelah erupsi tahun 2010 masyarakat lebih terbuka terhadap informasi dari luar. Kegiatan kelompok masyarakat juga diperkuat dengan adanya kegiatan penyusunan data penduduk terkait mitigasi bencana. Kelompok aktivitas masyarakat yang ada mulai terbuka terhadap berbagai informasi dari pemerintah sebagai informasi resmi dan ditindaklajuti dengan aktivitas mengungsi atas inisiatif sendiri.

Perubahan komunikasi juga memberikan dampak terhadap perubahan sikap dan perilaku masyarakat dalam mewaspadai bencana. Masyarakat setelah erupsi tahun 2010 lebih memiliki kesiapan untuk mengambil keputusan mengungsi seperti mempersiapkan alat transportasi pribadi dan mempersiapkan dokumendokumen yang perlu dibawa saat mengungsi. Dalam hal informasi mengenai situasi siaga masyarakat kini lebih memiliki inisiatif dalam mencari informasi dan memiliki sikap lebih siaga seperti misalnya dapat menentukan kapan saatnya mengungsi tanpa harus diperintahkan berulangkali oleh kepala dusun. Masyarakat juga mengetahui prioritas siapa saja anggota keluarga yang harus diungsikan tanpa menunggu komando dari kepala dusun. Selain itu masyarakat mengetahui juga pihak mana saja yang harus dihubungi untuk memperoleh bantuan.

Dari segi inovasi dalam saluran informasi mengenai bencana, masyarakat dan kepala dusun setempat telah menyusun panduan tertulis berisi data demografi penduduk yang terkait mitigasi bencana misalnya status tiap warga dari segi usia, kondisi fisik, alat transportasi yang dimiliki tiap keluarga, jumlah dan jenis ternak, alur pengungsian ternak, serta standart operasional evakuasi.

Alat komunikasi yang digunakan sebelum erupsi 2010 hanya mengandalkan informasi dari mulut kemulut dan menggunakan alat tradisional kentongan serta sirine, setelah erupsi tahun 2010 masyarakat mengandalkan alat komunikasi tambahan seperti HT (handy talkie) yang lebih banyak dimiliki disetiap RT serta senantiasa mengamati informasi dari menara pengawas gunung.

\section{Inovasi}

Difusi untuk inovasi mitigasi bencana perlu dilakukan evaluasi secara berkala. Karena bencana letusan gunung seringkali tidak dapat diprediksi kapan tepatnya siklus erupsi akan terjadi, akibat dari bencana serta perilaku aktivitas gunungnyapun bisa berubah. Masyarakat senantiasa perlu diingatkan bahwa pengetahuan lokal atau tradisional yang selama menjadi acuan perlu dikombinasikan dengan inovasi teknologi sehingga informasi yang diperoleh menjadi lebih akurat.

\section{Saluran komunikasi}

Penelitian ini memberikan beberapa rekomendasi untuk saluran komunikasi 
dalam mitigasi bencana gunung berapi. Pertama penting untuk dibuat papan petunjuk berupa informasi mengenai mitigasi bencana dibanyak lokasi dengan bentuk yang standar. Petunjuk tersebut harus mudah dibaca terutama dapat dibaca pada malam hari. Papan arah petunjuk hendaknya saling terintegrasi dengan lokasi penting lainnya seperti seperti titik kumpul, lokasi tempat tersedianya transportasi untuk mengungsi, tempat pengungsian, titik tempat hunian sementara, dan sebagainya. Media informasi tertulis dibuat dari bahan yang tidak mudah lekang karena cuaca dan tulisan atau gambarnya cepat pudar.

Kedua, petunjuk mengenai jalur evakuasi dan mitigasi bencana hendaknya menggunakan bahasa yang istilahnya lazim dipahami serta digunakan masyarakat setempat. Penggunaan gambar yang akan lebih efektif karena sebagian masyarakat masih ada yang belum dapat membaca sehingga penggunaan gambar lebih mempermudah untuk mengingat.

Ketiga, perlunya informasi mengenai tahapan tanda-tanda aktivitas gunung Merapi dalam bentuk gambar ataupun tulisan. Informasi dapat diletakkan di beberapa tempat umum seperti balai desa, masjid dan mushola atau tempat warga biasa berkumpul. Keempat, simulasi mengenai mitigasi bencana dalam kondisi normal perlu dilakukan secara rutin dan menggunakan berbagai macam cara agar menarik bagi masyarakat. Misalnya disampaikan pada saat pengajian rutin, dibuat dalam bentuk lomba tentang pengetahuan evakuasi, disampaikan dalam aktivitas belajar siswa disekolah, dalam bentuk permainan, sandiwara, pementasan wayang, cerita tradisional, pertukaran cerita dengan masyarakat dari dusun lain, dan sebagainya. Perlunya dilakukan pemutakhiran data penduduk terkait dengan mitigasi bencana secara berkala dan disampaikan ke masyarakat sehingga meskipun dalam situasi normal masyarakat selalu dalam kondisi yang siap siaga dalam menghadapi ancaman bencana.

\section{Daftar Pustaka}

Carter,W. Nick. (2008). Disaster Management: a Disaster Manager's Handbook. Philipines: Asian Development Bank.

Hirokawa, Randy Y, dan Salazar, Abran J. (1999). Task Group Communication and Decision-Making Performance in Frey, Lawrence R, Goran, Dennis S dan Poole, Marshal Scott, 1999, The Handbook of Group Communication Theory, Sage Publication Inc.

Littlejohn, Stephen W. Karen A. Foss. (2009). Encyclopedia of Communication Theory. California: SAGE Publications, Inc.

Maloney, Erin K. \& Coppola, Damon P. (2009). Communicating Emergency Preparedness: Strategic For Creating a Disaster Resilient. USA: Auerbach Publicationa Taylor \& Francis Group.

Mercer, Jessica, Kelman, Ilan \& Dekens, Julie. (2009). Integrating Indigenues and Scientific Knowledge For Disaster Risk Reduction, dalam Takeuchi, Yukiko, Sharma, Anshu, Shaw Rajib, Natural Disaster Research, Prediction and Mitigation Series. New York: Nova Science Publishers, Inc.

Miswanta. (2009). Problematika Penentuan Waktu Pengungsian, BPPTK, Pusat Vulkanologi dan Mitigasi Bencana Geologi, Badan Geologi .

Miller, Khaterine. (2005). Communication Theories, Perspectives, Pocesses, and Context ( $2^{\text {nd }}$ ed). Mc Graw Hill International Edition.

Polee, Marshal Scott. (1999). Group Communication Theory, in Frey, Lawrence R, Goran, Dennis S dan Poole, Marshal Scott, 1999, The Handbook of Group Communication Theory, Sage Publication Inc. 
Porifiev, Boris N. (1998). Issues in The Definition And Delineation Of Disaster s and Disasters Areas in Quarantelli. E. L, What Is A Disaster? Perspective on The Question. New York: Routledge.

Pramono, Adi Suryo \& Birowo, M. Antoniu (2012). Hidup Nyaman Bersama Ancaman: Pengalaman Radio Komunitas Lintas Merapi, Klaten, Jawa Tengah.

Wijanarko, Himawan. (2006). Disaster Management di Negeri Rawan Bencana. Jakarta: The Jakarta Consulting Grup.

Özerdem, Alpaslan \& Jacoby Tim. (2006). Disaster Management and Civil Society: Earthquake Relief in Japan, Turkey and India. London: I.B.Tauris \& Co Ltd.

Rogers, Evertt M. (1995). Diffusion of Innovation. New York: The Free Press.

Rogers, Evert M \& Kincaid, D. Lawrence. (1981). Communication Networks. New York: Free Press.

Ritchie, L. David. (1991). Communication Concept 2: Information, Sage Publication, New Delhi.

Sumadi, Dila. (2007). Komunikasi Pembangunan, Pendekatan Terpadu, Bandung: Sembiosa Rekatama Media.

Sorensen, John H, Sorensen, Barbara Voght. (2006). Community Processes: Warning and Evacuation dalam Rodriguez, Havidan, Qaurantelli, Enrico 1, Dynes, Rusell, Handbook of Disaster Research. USA: Springer Science + Business Media, LLC.

Soemarwoto, Otto. (2008). Ekologi, Ling k ungan Hidu p d a n Pembangunan Jambatan. Jakarta.

Shaw, Rajib, Sharma Anshu, Takeuchi Yukiko. (2009). Indegenous Knowledge and Disaster Risk Reduction, from Practice to Policy. New York: Nova Science Publishers Inc.

Sylves, Richard. (2008). Disaster Policy and Politics, Emergency management and Homeland Security. Washington DC:
CQPress.

\section{Tesis dan laporan penelitian}

Nugroho, Eko, Istiana, Purwani. (2012). Sistim Peringatan Dini Berbasis Masyarakat Untuk Mitigasi Bencana Merapi, Merapi Dalam Kajian Multidisiplin, Sekolah Pascasarjana UGM. (Tesis tidak diterbitkan). Universitas Gajah Mada, Yogyakarta, Indonesia.

Setyarto, Dwiatmodjo, Budi. (2012). Konflik Kebijakan dan Pengetahuan Lokal Dalam Pengurangan Risiko Bencana Erupsi Gunung Berapi Tahun 2010 di Kinahrejo/Palemsari, Desa Umbulharjo Kecamatan Cangkringan, Kabupaten Sleman, DIY. Pascasarjana Manajemen dan Kebijakan Publik Fakultas Ilmu Sosial dan Ilmu Politik Universitas Gadjah Mada Yogyakarta (Tesis tidak diterbitkan). Universitas Gajah Mada, Yogyakarta, Indonesia.

Wirasuta, Dadang S. (2013). Pelibatan TNI Dalam Penanggulangan Bencana Di Daerah Istimewa Yogyakarta. Laporan Hasil Penelitian, Lembaga Penelitian dan Pengabdian Masyarakat Universitas Pertahanan Indonesia. (Laporan penelitian tidak di terbitkan). Jakarta, Indonesia.

Kusumaningtyas, Purwanti. (2007). Intepretasi Ulang Makna spiritualitas bencana dalam cerita Rakyat Indonesia, Jurnal Kajian Politik Lokal danSosial, Humaniora (Vol1).

Artikel:

Martin R. Degg Martin and and K. David. (2005, (2 Juni Vol. 171). Seismic and Volcanic Hazards in Peru: Changing Attitudes to Disaster Mitigation, The Geographical Journal. pp. Published by: Wiley on behalf of The Royal Geographical Society with the Institute of British Geographers, hal.125-145. 
Oman Abdurahman, Eddy Mulyadi, Priatna, Prima M. Hilman, Joko Parwata dkk (2006, Mei). Karsima Gunung Merapi, dari Internet ke Dunia Nyata, artikel Refleksi Untuk Penyajian Informasi dan Mitigasi Bencana Gunung Api, Warta Geologi.

\section{Artikel Surat Kabar:}

B. E. Julianery. (2010, November 05). Adaptasi Mengubah Paradigma Mengatasi Bencana. Koran Kompas, hal. 48 .

Damayanti, Doty. (2010, Desember 20). Manajemen Bencana Mendorong Mitigasi Bencana Berbasis Resiko. Koran Kompas, hal. 42.

Arif, Ahmad. (2015, April 05). Gunung Api : Dua Abad Letusan Tambora. Koran Kompas, hal. $1 \& 15$.

\section{Tulisan/Berita dalam surat kabar tanpa pengarang:}

Asia Paling Banyak Dilanda Bencana. (2012, Oktober 20). Koran Kompas, hal:13.

Bencana Gunung Api: Penduduk Indonesia Paling Terancam. (2014, April 13). Koran Kompas, hal:13.
Artikel Jurnal:

Kusumasari, Bevaola \& Alam, Quamrul. (2011, November 10). Bridging The Gaps: The Role of Local Government Capability and The Management of a Natural Disaster in Bantul, Indonesia. Springer Science+Business Media B.V. 2011Nat Hazards (2012) 60:761-779 DOI10.1007/s11069-011-0016-1.

\section{Sumber lain :}

Undang-Undang Republik Indonesia Nomor 24 Tahun 2007 tentang Penanggulangan Bencana.

Peraturan Presiden Republik Indonesia Nomor 8 Tahun 2008 Tentang Badan Nasional Penanggulangan Bencana.

Dokumen Tim Pengurangan Resiko Bencana Parikesit, 2014, Sumber Matriks Data Kependudukan Aset dan SOP Dusun KalitengahKidul Desa GalagahHarjo Kabupaten Sleman, Daerah Istimewa Yogyakarta. 